\title{
11. AUTHIGENIC SILICA IN TERTIARY AND UPPER CRETACEOUS SEDIMENTS OF THE EAST MARIANA BASIN, DEEP SEA DRILLING PROJECT SITE 585 ${ }^{1}$
}

\author{
Miriam Baltuck, Department of Geology, Tulane University²
}

\begin{abstract}
Siliceous sediments and sedimentary rocks occur as chert and silicified chalk, limestone, and claystone in Site 585 lower Miocene to Campanian sediments, with one older occurrence of chert near the Cenomanian/Turonian boundary. The recovered drill breccia in the Miocene to middle Eocene interval is dominated by bright red, orange, yellow, and brown chips and fragments of chert. In early Eocene and older sediments gray silicified limestone and yellowish brown chert fragments predominate. Recovery is poor in cores with chert because chert tends to fracture into smaller pieces that escape the drill and because the hard chert fragments grind away other sediments during rotary drilling.

Thin-section and hand-sample studies show complex diagenetic histories of silicification (silica pore infill) and chertification (silica replacement of host rock). Multiple events of silicification can occur in the same rocks, producing chert from silicified limestone. Despite some prior silicification, silicified limestone is porous enough to provide conduits for dissolved silica-charged pore waters. Silicification and chert are more abundant in the coarser parts of the sedimentary section. These factors reflect the importance of porosity and permeability as well as chemical and lithologic controls in the process of silica diagenesis.
\end{abstract}

\section{INTRODUCTION}

Considerable progress has been made in the study of authigenic silica formation, and excellent reviews can be found in Kastner (1981) and Iijima et al., (1983). Much debate in the 1970 s concerned rates and mechanisms of diagenesis. Many workers (e.g., Calvert, 1974; Heath and Moberly, 1971; von Rad and Rösch, 1972; Riech and von Rad, 1979) described a process in which biogenic silica (amorphous opal or opal-A; terminology after Jones and Segnit, 1975) matures through an opal-CT disordered cristobalite-tridymite phase to microcrystalline quartz; dissolution of biogenic silica and precipitation of opal-CT was a first step in several of these models. Lancelot (1973) documented a similar diagenetic sequence but one that is slower and less complete in clay-rich sediment than in calcareous sediment. These workers generally attributed the silica to a biogenic source but suggested that volcanic processes could be locally significant sources or sinks (Calvert, 1974, Wollast, 1974). Experimental laboratory work by Kastner et al. (1977) and Kastner and Gieskes (1983) indicates a basis for both models.

Silica diagenesis most commonly follows a path of:

$$
\text { opal-A } \rightarrow \text { opal-CT } \rightarrow \text { microcrystalline quartz }
$$

via two dissolution-precipitation steps. The rate and completeness of diagenesis correlates with the composition of the host lithology. The key factor in the lithologic control is the presence in solution of $\mathrm{Mg}(\mathrm{OH})_{2}$, which serves as a nucleus for precipitation of opal-CT. Calcareous sediments can enrich interstitial waters in dissolved

\footnotetext{
${ }^{1}$ Moberly, R., Schlanger, S. O., et al., Init. Repts. DSDP, 89: Washington (U.S. Govt. Printing Office).

2 Address: Department of Geology, Tulane University, New Orleans, LA 70118.
}

$\mathrm{Mg}^{++}$and thus promote opal-CT precipitation. However, clay minerals tend to absorb $\mathrm{Mg}^{++}$onto their surfaces and thus retard opal-CT formation. The relationship of silica diagenesis to lithology can therefore be explained in terms of availability of $\mathrm{Mg}^{++}$and $(\mathrm{OH})^{-}$in solution (Kastner et al., 1977). Although volcanic processes may locally contribute dissolved silica to seawater, it is generally considered that the source of most authigenic silica in marine sediments is biogenic (e.g., Keene, 1976; Kastner, 1981; Kelts, 1976).

The exact mechanism by which the dissolution-precipitation steps occur is still not clear, mainly because there is so much apparent variation in preserved textures and chemical composition (Baltuck, 1983). For example, delicate structures in a completely recrystallized radiolarian cast may be faithfully preserved, whereas in the same lithologic unit-even within the same thin section-other primary features may be nearly or completely obliterated by silicification. Riech and von Rad (1979) relate sharp or fuzzy boundaries to the degree of host sediment consolidation and the level of saturation of interstitial waters with respect to silica.

In this chapter I describe some of the silica cementation and replacement textures observable in thin sections and in hand samples from Site 585. These textures are interpreted with respect to porosity and carbonate content data, and the primary textures of the host lithology. This information provides constraints for models of replacement silica diagenesis, specifically about when and on what scale these diagenetic reactions occur, and about the effect of silica diagenesis on the texture of the host rock.

\section{GEOLOGIC SETTING}

Deep Sea Drilling Project (DSDP) Holes 585 and 585A were drilled in a water depth of about $6100 \mathrm{~m}$ as singlebit attempts to reach the Jurassic basalt presumed to lie 
beneath the Mariana Basin (Introductory chapter, this volume; Fig. 1). Six lithologic units were recognized in a sequence of sediments that consists almost entirely of debris flows and subsequent turbidite deposits. Both holes terminated in well-cemented Aptian-Albian volcaniclastic sediments (Site 585 report, this volume).

Silicified sediments occur in lithologic Units II-IV (middle Eocene to Campanian), with one occurrence in Unit V (Cenomanian/Turonian boundary) (Table 1). The sediments were deposited at a latitude close to the equator (estimates range from $8^{\circ} \mathrm{S}$ to $5^{\circ} \mathrm{N}$ from 60 to $70 \mathrm{Ma}$ : Lancelot and Larson, 1975, p. 1926; Ogg, this volume) and now exist as chert and silicified claystone in claystone sequences at a latitude of $13^{\circ} 29^{\prime} \mathrm{N}$. The Mariana Basin is bounded by the Magellan Seamounts to the north, the Caroline Islands to the south, an unnamed seamount group east, and the Mariana Trench to the west. Site 585 lies on the northeast edge of the Basin near DSDP Sites 199 and 202.

The youngest chert-bearing sediment is possibly early Miocene in age (Unit II). It occurs in a wash core that spans early Miocene to middle Eocene. Multicolored (yellow, orange, brown, and red) chert fragments within a nannofossil chalk host lithology and fragments of this host rock are the dominant materials recovered down to $275 \mathrm{~m}$ sub-bottom (middle Eocene). Below this, brightly colored chert still occurs, but the drill breccia composition is dominated by light gray silicified limestone "peppered" with silicified foraminifers and by yellowish brown chert (Unit III). The host lithology remains nannofossil chalk (Eocene and Paleocene). Maestrichtianupper Campanian calcareous claystone and chalk contain layers of silicified claystone, silicified chalk, and brown chert nodules (Unit IV). Fragments of Campanian chert that replaced graded bioclastic limestone are the sole recovery of Cores $585-23$ to -26 . Finally, brightly colored chert pieces in Core 585A-9 lie close to the organic carbon-rich layer in that core associated by shipboard scientists with the Cenomanian-Turonian oceanic anoxic event (Unit V) (see Schlanger and Moberly, this volume). Host lithology throughout Holes 585 and 585A was evidently redeposited (Whitman et al., this volume).

In this discussion of authigenic silica occurrences, I use the terms "silicified" and "chertified" to denote two different processes. In a silicified sediment the host rock is a chalk, limestone, or claystone in which the pores have largely been filled by silica cement (microcrystalline quartz or opal-CT in Site 585 sediments). The rock still retains some carbonate but can be distinguished from adjacent host nannofossil chalk in hand sample by its slightly darker color, greater hardness, and weak (or lack of) reaction to $10 \%$ hydrochloric acid $(\mathrm{HCl})$. I use "chert" to designate a rock composed almost entirely of silica that formed by filling of pore space by silica and by replacement of host carbonate and claystone by silica. Chert is distinguished from silicified limestone on the basis of its lustrous appearance, conchoidal fracture, generally more vivid color, and lack of reaction to $\mathrm{HCl}$. Recovery was poor in intervals containing chert, and the great difference in hardness between chert and host lithology generally resulted in the grinding away of immediately adjacent host rock from chert pieces during drilling.

\section{SILICIFIED LIMESTONE}

Silicified limestone is most common in Site 585 Unit II (Cores $585-4$ to $-6,-9$ to -15 , and -17 ) in a host chalk of middle Miocene to Maestrichtian age. In thin section the matrix of silicified limestone is microcrystalline cristobalite and quartz, based on shipboard X-ray diffraction (XRD), with minor microspar. Microfossils (mostly radiolarian tests, interior molds, and ghosts of foraminifers) are generally complete rather than fragmented. The quality of preservation of initial host rock textures varies considerably. The percent of carbonate composition in the chalk unit varies from $20 \%$ (silicified limestone) to over $85 \%$ (siliceous chalk); see Table 2 . The presence of carbonate in the silicified limestone and of microfossils that have not been broken by compaction suggests that early silicification of the nannofossil ooze involves silica cementation infilling pore space rather than replacement of carbonate (Fig. 2). A simple calculation based on the density and porosity differences between the host nannofossil chalk and the silicified limestone supports this suggestion. Using the data averaged from Table 2, a predicted bulk density of nannofossil chalk is obtained by adding:

$\left[(1-\%\right.$ porosity $\left.) \times\left(2.72 \mathrm{~g} / \mathrm{cm}^{3}\right)\right]+\left[(\%\right.$ porosity $\left.) \times\left(1.03 \mathrm{~g} / \mathrm{cm}^{3}\right)\right]$

with $2.72 \mathrm{~g} / \mathrm{cm}^{3}$ being the density of calcite and $1.03 \mathrm{~g} /$ $\mathrm{cm}^{3}$ the density of seawater, which approximates the density of the interstitial water. The calculated bulk density of seawater-saturated nannofossil chalk with a present porosity of $49.3 \%$ is $1.88 \mathrm{~g} / \mathrm{cm}^{3}$. This figure is close to the average measured bulk density obtained by gravimetric technique $\left(1.84 \mathrm{~g} / \mathrm{cm}^{3}\right)$ (Table 3). If we assume that the porosity difference between chalk and silicified limestone is entirely accountable by silica infill of pore spaces, then a bulk density for the silicified limestone can be calculated by using the previously calculated term for nannofossil chalk, the measured porosity of silicified limestone, and the difference in porosity between nannofossil chalk and silicified limestone:

$$
\begin{aligned}
& {\left[\left(1-\% \text { porosity }_{\text {chalk }}\right) \times\left(2.72 \mathrm{~g} / \mathrm{cm}^{3}\right)\right]+} \\
& {\left[(\% \text { porosity } \text { silicified limestone }) \times\left(1.03 \mathrm{~g} / \mathrm{cm}^{3}\right)\right]+} \\
& {\left[\left(\% \text { porosity } y_{\text {chalk }}-\% \text { porosity } \text { silicified limestone }\right) \times\left(2.3 \mathrm{~g} / \mathrm{cm}^{3}\right)\right]}
\end{aligned}
$$

with $2.3 \mathrm{~g} / \mathrm{cm}^{3}$ being the density of cristobalite. The calculated density of a silicified limestone is thus $1.99 \mathrm{~g} /$ $\mathrm{cm}^{3}$, again close to the average measured gravimetric density value of $1.94 \mathrm{~g} / \mathrm{cm}^{3}$. Both predicted values are about $0.04 \mathrm{~g} / \mathrm{cm}^{3}$ greater than the measured average of two values, an artifact in the second calculation inherited from the excess in the first.

Evidence that silicification was an early diagenetic process is provided by the fortuitous presence of small (2-mm), dark, horizontal lenses of zeolitic clay in the host rock, particularly in Cores 585-12 to -14. The zeolitic clay occurs in subspherical bodies probably representing filled burrows in both silicified limestone and 


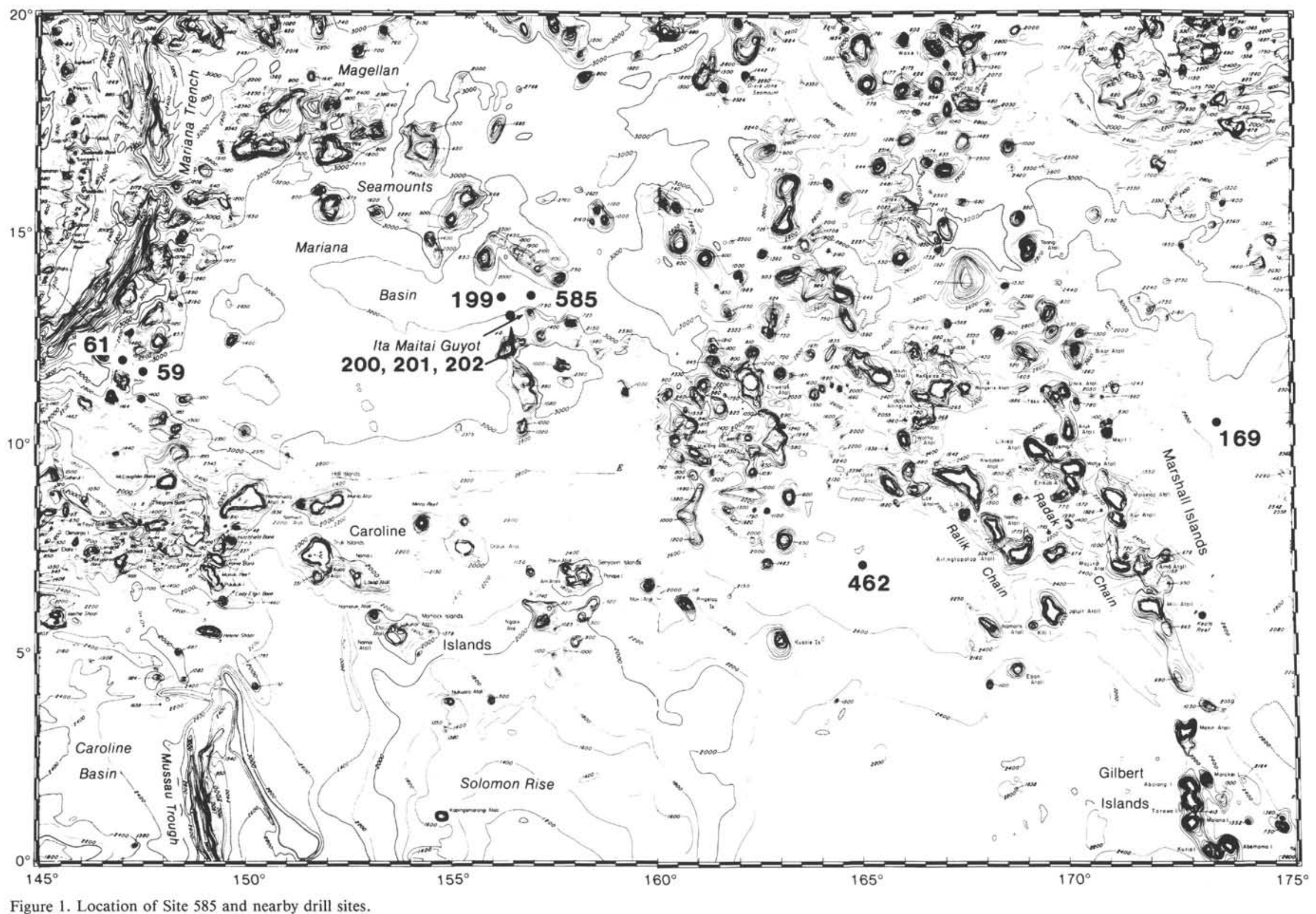


Table 1. Chert occurrences at Site 585.

\begin{tabular}{|c|c|c|c|c|}
\hline $\begin{array}{l}\text { Sample } \\
\text { (hole-core-section, } \\
\text { interval in } \mathrm{cm} \text { ) }\end{array}$ & $\begin{array}{l}\text { Sub-bottom } \\
\text { depth } \\
\text { (m) }\end{array}$ & Age & $\begin{array}{c}\text { Host } \\
\text { lithology }\end{array}$ & Description \\
\hline 585-H1 & $6.8-255.9$ & e. Miocene-m. Eocene & Nannofossil chalk & $\begin{array}{l}\text { Multicolored fragments }(21 \mathrm{~cm}) \text { of chert } \\
\text { in wash-core, some with rim of host } \\
\text { chalk intact }\end{array}$ \\
\hline $585-2, \mathrm{CC}$ & $255.9-265.5$ & m. Eocene & Nannofossil chalk & $\begin{array}{l}\text { Drilling breccia of multicolored chert } \\
\text { fragmenis as above; } \\
\text { dominant colors are dark yellow } \\
\text { brown }(10 \text { YR } 4 / 2) \text {, gray brown } \\
\text { (10YRS/2), and very pale brown } \\
\text { (10YR } 7 / 3) \text {; some of the larger chert } \\
\text { fragments have partial rim of very } \\
\text { pale orange }(10 Y R 8 / 2) \text { silicified } \\
\text { nannochalk }\end{array}$ \\
\hline $585-3-1$ and $C C$ & $265.5-275.1$ & m. Eocene & Nannofossil chalk & $\begin{array}{l}\text { Drill breccia as above, with dominant } \\
\text { colors of reddish brown (SYRS/3-4/4), } \\
\text { light reddish brown (5YRS/6), and } \\
\text { grayish orange }\end{array}$ \\
\hline $585-4, \mathrm{CC}$ & $275.1-279.1$ & m. Eocene & Nannofossil chalk & $\begin{array}{l}\text { Fragments of brightly colored chert as } \\
\text { above, but drill breccia is dominated } \\
\text { by light gray (10YR8/1) silicified } \\
\text { limestone "peppered" with sand-sized } \\
\text { silicified foraminifers }\end{array}$ \\
\hline $585-5 . \mathrm{CC}$ & $279.1-284.6$ & m.? Eocene & Nannofossil chalk & $\begin{array}{l}\text { Dark yellowish brown (10YR3/4) chert } \\
\text { caps a piece of white (N9) nannofossil } \\
\text { chalk in a 15-cm interval; other chert } \\
\text { fragments of yellowish brown } \\
(10 \mathrm{YR} 7 / 2) \text { to dark yellowish brown } \\
(10 \mathrm{YR} 4 / 2) \text { color occur in drill breccia }\end{array}$ \\
\hline $585-6-2$ & $284.6-293.7$ & m.? Eocene & $\begin{array}{l}\text { Nannofossil chalk and } \\
\text { limestone }\end{array}$ & $\begin{array}{l}\text { Chips and fragments of multicolored chert } \\
\text { and silicified limestones }\end{array}$ \\
\hline $585-7-1$ & $293.7-302.9$ & m. Eocene & Nannofossil chalk & $\begin{array}{l}S \text { fragments of several } \mathrm{cm} \text { diameter of } \\
\text { dark yellowish brown (10YR3/4) chert } \\
\text { with partial rims of white (N9) silici- } \\
\text { fied chalk }\end{array}$ \\
\hline 585-10-1 and CC & $321.3-330.3$ & e. Eocene & Nannofossil chalk & $\begin{array}{l}\text { Chips of white (N8) to light gray (5Y7/1) } \\
\text { silicified limestone and brown } \\
\text { (10YRS/6 and 10YR3/4) chert }\end{array}$ \\
\hline $585-12-1$ and 2 & $339.5-348.6$ & e. Eocene & $\begin{array}{l}\text { Nannofossil chalk with thin } \\
\text { lenses of zeolitic clay }\end{array}$ & $\begin{array}{l}\text { Light gray }(5 Y R 7 / 1) \text { silicified limestone in } \\
\text { several layers; some pieces contain } \\
\text { subspherical pockets of zeolitic clay } \\
\text { implying that silicification preceded } \\
\text { compaction of zeolite to lenses }\end{array}$ \\
\hline $585-13-1,0-82$ & $348.6-349.4$ & e. Eocene & $\begin{array}{l}\text { Nannofossil chalk with thin } \\
\text { lenses of zeolitic clay }\end{array}$ & As in sample above \\
\hline $585-14-2,79-102$ & $361.2-361.4$ & c. Eocene & Nannofossil chalk & $\begin{array}{l}\text { Light gray (SYR } 7 / 1) \text { silicified nannofossil } \\
\text { chalk, bioturbated at base }\end{array}$ \\
\hline $585-15-1,2$ and $C C$ & $366.9-380.4$ & e. Paleocene & Nannofossil chalk & $\begin{array}{l}\text { Silicified limestone in chalk; mostly light } \\
\text { gray }(10 Y R 6.5 / 1) \text {, pale brown } \\
\text { (10YR6/3) and zeolite lenses at base } \\
\text { with brown chert fragments in core } \\
\text { catcher }\end{array}$ \\
\hline $585-16-1,108-113$ & $381.5-381.6$ & e. Paleocene & Nannofossil chalk & Dark brown (10YR4/3) chert \\
\hline $585-17-1,42-75$ & $389.9-390.3$ & Maestrichtian & $\begin{array}{l}\text { Nannofossil chalk of varied } \\
\text { degrees of induration; } \\
\text { contact with upper and } \\
\text { under claystone beds } \\
\text { sharp }\end{array}$ & Silicified limestone \\
\hline $\begin{array}{l}585-18-1,140-150 \\
\text { and }\end{array}$ & $400.1-400.2$ & Maestrichian & $\begin{array}{l}\text { Pale green calcareous } \\
\text { claystone }\end{array}$ & Brown (5YR3/4) chert nodules \\
\hline $\begin{array}{l}585-18-2,20-30 \\
585-19-1,50-81\end{array}$ & $400.4-400.5$ & & Calcareous zeolitic clay. & Brown chert nodules \\
\hline $585-19-1,50-81$ & $408.3-408.6$ & Maestrichian & & \\
\hline $585-20-1,30-50$ & $417.3-417,5$ & Maestrichian & $\begin{array}{l}\text { Zeolite lenses calcareous } \\
\text { claystone }\end{array}$ & Brown chert nodules \\
\hline 585-21-1, and $\mathrm{CC}$ & $426.1-426.9$ & late Campanian & $\begin{array}{l}\text { Calcareous claystone and } \\
\text { chalk }\end{array}$ & $\begin{array}{l}\text { Light brown }(7.5 Y R 6 / 4) \text { silicified lime- } \\
\text { stone and pale green (SG8/2) chert }\end{array}$ \\
\hline $585-23, \mathrm{CC}$ & $444.4-444.6$ & Campanian & Graded bioclastic limestone & $\begin{array}{l}\text { Three pieces of chert showing graded } \\
\text { bedding, bioturbation }\end{array}$ \\
\hline $585-24, C C$ & $453.6-453.8$ & Campanian & Bioclastic limestone & $\begin{array}{l}\text { One piece of chert with grading, lamina- } \\
\text { tion, bioturbation }\end{array}$ \\
\hline $585-25, \mathrm{CC}$ & $462.7-462.9$ & Campanian & $\begin{array}{l}\text { Limestone? calcareous } \\
\text { claystone }\end{array}$ & Five pieces of chert as above \\
\hline $585-26-1$ & $476.3-477.0$ & Campanian & Zeolitic claystone (2) & $\begin{array}{l}\text { Fragments of dark brown }(7.5 Y R 4 / 4) \text { and } \\
\text { bight olive gray (5YR5/2) chert } \\
\text { Multicoled }\end{array}$ \\
\hline $585 \mathrm{~A}-1.2$ and $\mathrm{CC}$ & $53.0-553.2$ & Cenomanian(?) & $\begin{array}{l}\text { Radiolarian-rich limestone } \\
\text { and claystone } \\
\text { Nannofossil chalk }\end{array}$ & $\begin{array}{l}\text { Multicolored chert in shades near 10YR } \\
\text { brown } \\
\text { Pale yellowish brown }(10 \mathrm{YR} 6 / 2) \text { chert }\end{array}$ \\
\hline $585 \mathrm{~A}-1.2$ and $\mathrm{CC}$ & $364.8-365.5$ & Paleocene & Nannofossil chalk & $\begin{array}{l}\text { Pale yellowish brown }(10 \mathrm{Y} R 6 / 2) \text { chert } \\
\text { fragments and silicified limestone }\end{array}$ \\
\hline $585 \mathrm{~A}-2-1$ & $373.3-374.1$ & e. Paleocene & Nannofossil chalk & $\begin{array}{l}\text { Moderate orange pink (5YR8/4) silicified } \\
\text { limestone and light brown (5YR6/4) } \\
\text { chert }\end{array}$ \\
\hline $585 \mathrm{~A}-3$ & $383.9-385.0$ & Maestrichian & Clayey Nannofossil chalk & $\begin{array}{l}\text { Silicified limestone and a few fragments } \\
\text { of brown }(5 Y R 3 / 4) \text { chert in drilling } \\
\text { disturbed core }\end{array}$ \\
\hline $585 \mathrm{~A}-\mathrm{H}-2$ & $392.3-438.2$ & $?$ & Nannofossil chalk & $\begin{array}{l}\text { Silicified limestone and chert in drill } \\
\text { breccia }\end{array}$ \\
\hline $585 \mathrm{~A}-4-1,0-20$ & $438.2-438.4$ & ? & ? & $\begin{array}{l}\text { Drill breccia with chips of dark brown } \\
\text { (10YR } 4 / 3 \text { ) chert }\end{array}$ \\
\hline $585 \mathrm{~A}-\mathrm{H} 3$ & $447.7-502.6$ & 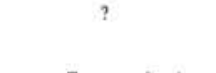 & ant & $\begin{array}{l}\text { Drill breccia composed mainly of dark } \\
\text { brown laminated, graded, bioturbated } \\
\text { chert }\end{array}$ \\
\hline $585 \mathrm{~A}-9-1,80-90$ & $544.3-544.5$ & $\begin{array}{l}\text { upper Cenomanian/ } \\
\text { Turonian }\end{array}$ & $\begin{array}{l}\text { Slightly calcareous siliceous } \\
\text { silt/claystone }\end{array}$ & $\begin{array}{l}3 \text { multicolored chert fragments in bright } \\
\text { shades of red, brown, yellow contain- } \\
\text { ing pyrite lenses directly overlying a } \\
\text { thin }(<2-\mathrm{cm}) \text { band of organic carbon- } \\
\text { rich sediment }\end{array}$ \\
\hline
\end{tabular}


Table 2. Select carbonate bomb results, Units II, III, and IV, Hole 585 .

\begin{tabular}{|c|c|c|c|}
\hline $\begin{array}{c}\text { Sample } \\
\text { (core-section, } \\
\text { interval in } \mathrm{cm} \text { ) }\end{array}$ & $\begin{array}{l}\text { Sub-bottom } \\
\text { depth } \\
\text { (m) }\end{array}$ & $\underset{(\%)}{\mathrm{CaCO}_{3}}$ & Lithology \\
\hline $6-1,28-32$ & 284.88 & 63 & Nannofossil chalk \\
\hline $6-1,119-120$ & 285.79 & 27 & $\begin{array}{l}\text { Laminae from nan- } \\
\text { nofossil limestone }\end{array}$ \\
\hline $8-1,16-17$ & 303.06 & 64 & Nannofossil chalk \\
\hline $8-2,12-14$ & 303.52 & 57 & Nannofossil chalk \\
\hline $8, \mathrm{CC}$ & 306.50 & 56 & Nannofossil chalk \\
\hline $10-1,39-42$ & 321.59 & 77 & Nannofossil chalk \\
\hline $10, \mathrm{CC}(3-5)$ & 327.00 & 32 & Nannofossil chalk \\
\hline $11-1,98-100$ & 331.30 & 78 & Nannofossil chalk \\
\hline $11-2,110-112$ & 332.90 & 34 & Silicified chalk \\
\hline $12-2,57-58$ & 341.57 & 83 & Nannofossil chalk \\
\hline $13-1,94-95$ & 349.54 & 0 & Zeolitic clay \\
\hline $13, \mathrm{CC}(3-7)$ & 351.50 & 74 & Nannofossil chalk \\
\hline $13-1,53-56$ & 349.10 & 52 & Silicified limestone \\
\hline $14-1,64-67$ & 358.44 & 76 & Nannofossil chalk \\
\hline $14-2,75-79$ & 360.05 & 77 & Nannofossil chalk \\
\hline $14-2,92-94$ & 360.97 & 53 & $\begin{array}{l}\text { Silicified nannofossil } \\
\text { limestone }\end{array}$ \\
\hline $14-2,105-108$ & 361.10 & 0 & Zeolitic claystone \\
\hline $15-1,34-36$ & 367.24 & 18 & Silicified limestone \\
\hline $15-1,61-62$ & 367.51 & 0 & Claystone \\
\hline $15-1,86-88$ & 367.76 & 0 & Claystone \\
\hline $15-1,98-100$ & 367.90 & 0 & Zeolitic claystone \\
\hline $15-1,113-114$ & 368.03 & 41 & Silicified limestone \\
\hline $15-1,129-130$ & 368.19 & 85 & Nannofossil chalk \\
\hline $16-1,22-23$ & 380.62 & 49 & Clayey nannochalk \\
\hline $16-1,69-70$ & 381.90 & 0 & $\begin{array}{l}\text { Zeolite-bearing } \\
\text { claystone }\end{array}$ \\
\hline $17-1,67-73$ & 390.17 & 72 & Nannofossil chalk \\
\hline $17-1,104-105$ & 390.54 & 36 & Silicified limestone \\
\hline $17-1,140-141$ & 390.90 & 60 & Nannofossil chalk \\
\hline $17-2,18-23$ & 391.18 & 51 & Chalk \\
\hline $17-2,7-9$ & 391.07 & 83 & Chalk \\
\hline $17-2,52-53$ & 391.52 & 0 & Claystone \\
\hline $17-2,75-79$ & 391.75 & 77 & Chert (?) \\
\hline $18-1,13-15$ & 398.83 & 27 & Claystone \\
\hline $18-1,53-56$ & 399.23 & 43 & Calcareous claystone \\
\hline $19-1,38-40$ & 408.18 & 57 & Nannofossil chalk \\
\hline $19-1,48-49$ & 408.28 & 76 & Nannofossil chalk \\
\hline $19-1,56-57$ & 408.36 & 0 & Claystone \\
\hline $20-1,8-16$ & 417.08 & 66 & $\begin{array}{l}\text { Nannofossil bearing } \\
\text { clay }\end{array}$ \\
\hline $20-2,12-18$ & 418.62 & 0 & Claystone \\
\hline $20-3,20-26$ & 418.70 & 79 & $\begin{array}{l}\text { Nannofossil-bearing } \\
\text { clay }\end{array}$ \\
\hline
\end{tabular}

chert, whereas they are flattened to lenticular shape in the host rock. This suggests that silicification of the nannofossil ooze occurred before the sediment was significantly compacted. Further evidence of early diagenetic silicification is that in Unit II there was no recovery of calcite-cemented limestone. All carbonates recovered were either chalk or silicified limestone, indicating silicification occurred before sediments were sufficiently buried to develop pressure-solution features or for calcite cementation to produce limestone.

If early silicification did occur, it is surprising that the simple density calculation agreed so well with the measured values; it might be expected that early pore filling by cristobalite $(\rho=2.33)$ would result in a rock less dense than material that owes its diminished porosity to compaction of calcite $(\rho=2.72)$.

\section{CHERT}

Chert as distinguished from silicified limestone occurs in the same units as silicified limestone but generally appears in cores of low recovery, which is due both

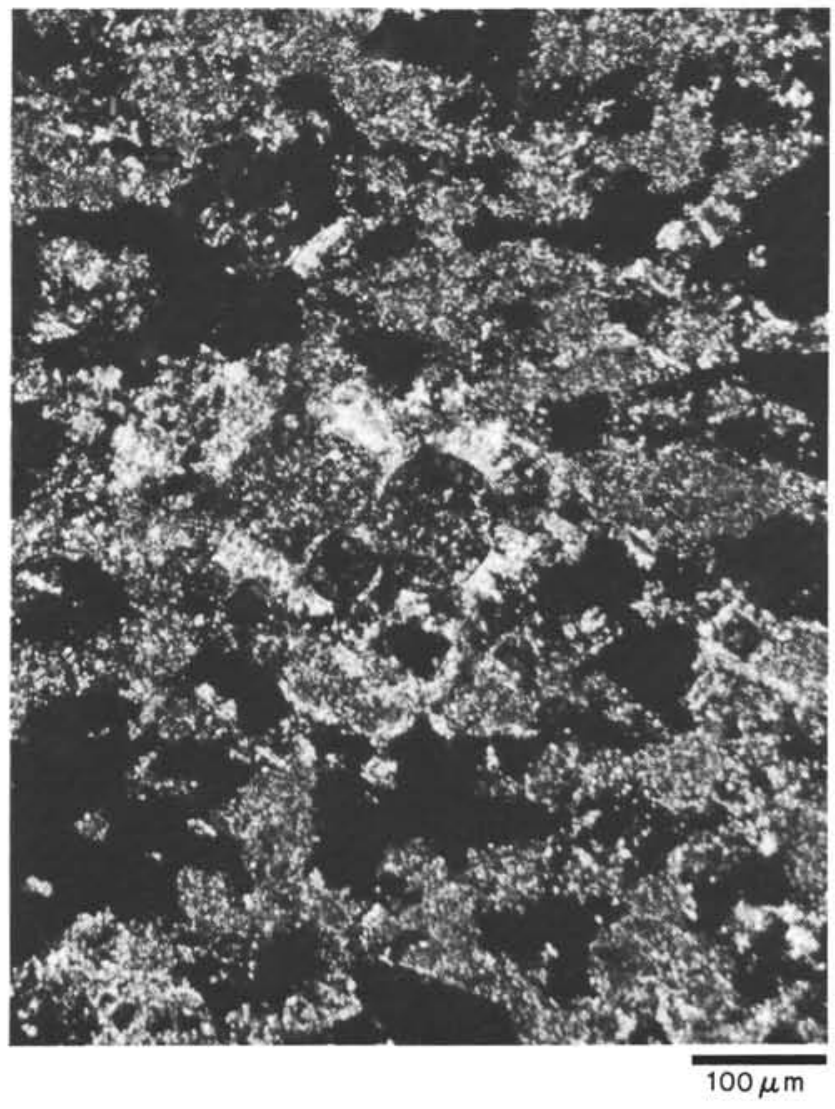

Figure 2. Photomicrograph of silicification (infilling) of microfossils and primary pore space (Sample $585-14, \mathrm{CC},[9-11 \mathrm{~cm}]$ ), early Eocene.

Table 3. Bulk density and porosity values for silicified nannofossil limestone and nannofossil chalk. ${ }^{\text {a }}$

\begin{tabular}{llcc}
\hline $\begin{array}{c}\text { Sample } \\
\text { (hole-core-section, } \\
\text { interval in cm) }\end{array}$ & Lithology & $\begin{array}{c}\rho \text { gravity } \\
\left(\mathrm{g} / \mathrm{cm}^{3}\right)\end{array}$ & $\begin{array}{c}\text { Porosity } \\
(\%)\end{array}$ \\
\hline $585-13-1,38-40$ & Silicified nannofossil chalk & 1.95 & 37.5 \\
$585-21-1,37-39$ & Silicified nannofossil chalk & 1.92 & 44.6 \\
& & 1.94 & 41.1 \\
Average of two & & 1.83 & 49.8 \\
& & 1.84 & 48.8 \\
$585-12-1,16-18$ & Nannofossil chalk & 1.84 & 49.2 \\
\hline
\end{tabular}

a From Site 585 report, this volume.

to the grinding away of host rock by chert fragments and the tendency of chert to shatter under a drill bit (the small pieces of rock tend to escape the bit).

Chertification involves replacement of original material by microcrystalline silica, usually quartz. Thin section studies (Fig. 3) shows that the chertified zones are separated from the siliceous limestone by boundaries that are either (1) gradational over a "chertification front" a few millimeters thick or (2) sharp over a distance of less than a millimeter. The edge of a sharp chertification front may be accentuated by a concentration of less soluble material (Fe-oxides or clay stringers or both). In addition chert occurs intermittently along well-defined 

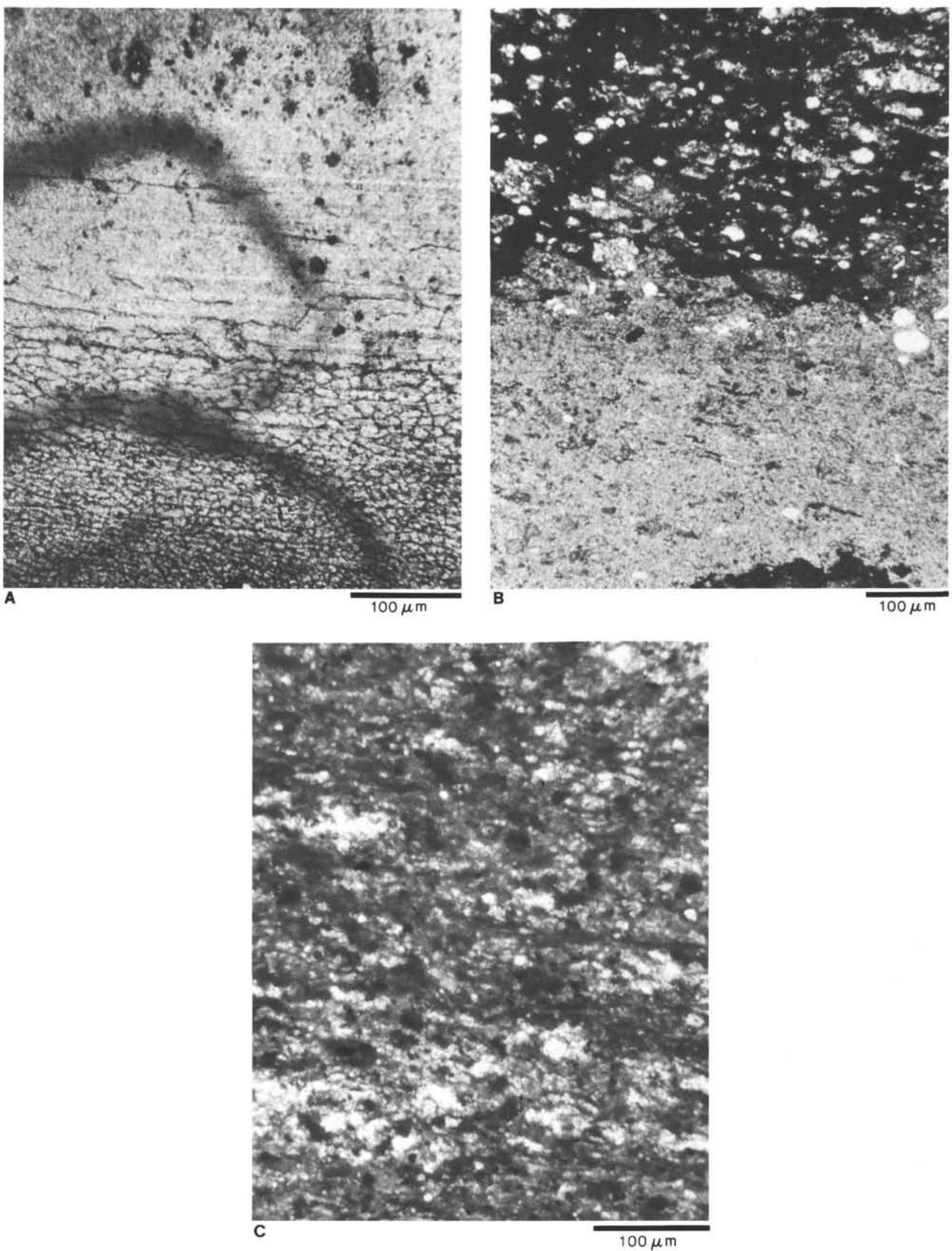

Figure 3. Silicification and chertification boundaries. A. Gradual replacement and recrystallization of silicified limestone by cherty quartz (Sample 585-3-1, 83-85 cm), middle Eocene; large dark lines are from etching on the glass slide). B. Rather sharp boundary between chert- and silica-cemented calcareous radiolarian claystone (Sample 585-34-2, 83-85 cm), Cenomanian. C. Partial silicification through infilling of pore space in coarser-grained laminae (Sample 585-23,CC [12-17 cm]), Campanian. 
layers within laminated siliceous limestone. The lithologic composition of the laminated limestone varies in grain size and possibly composition in the original sediment (Fig. 4).

Although the porosity of silicified limestone is much less than that of chalk (see Table 3 ), some initial porosity is a prerequisite of chertification. Figure 5 illustrates how chertification has been halted by impermeable chalcedony veins that cut across the silicified limestone, effectively sealing it to fluid movement. The result is a sharp textural break defined by a thin vein of chalcedonic quartz; chert occurs on one side of the vein and silicified limestone on the other.

The timing of chertification is difficult to estimate. Where chert appears within silicified material it is obviously a replacement and thus a postsilicification phenomenon. It is not unusual to find inclusions of siliceous limestone within chert that have not been entirely replaced (e.g., Sections 585-5-1 and 585-11-1; Fig. 6). It is also common to find isolated, sharply outlined occur-

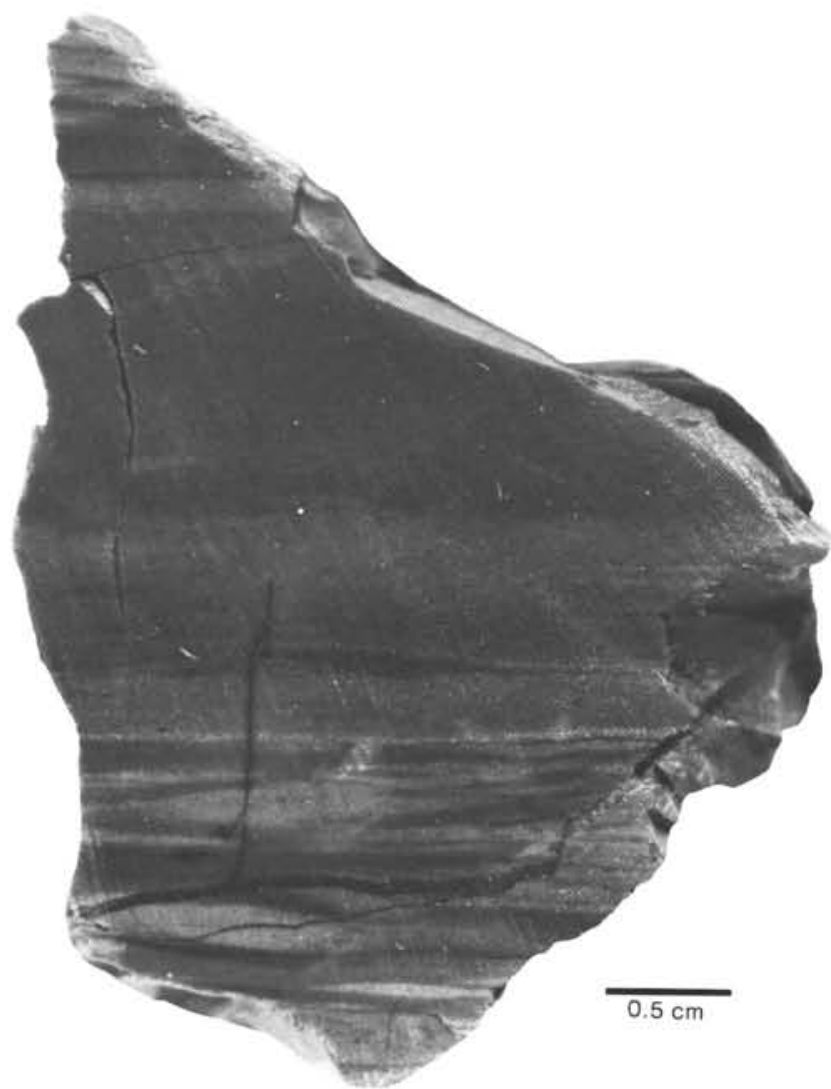

Figure 4. Sample 585-24,CC. One of four pieces of Campanian chert that constitute the entire recovery of Core 585-24. Lenticular laminations mix various shades of brown (10YR 4/3), yellowish brown (10YR 3/4), dark brown (10YR 3/3), and intermediate shades. Texture suggests the chert formed by silicification of bioclastic granular limestone with fine lenticular banding of possible burrow origin. Alternatively, seafloor winnowing may have concentrated sandsize clasts in small lenses. A graded interval fines upward from the light sandy horizontal band that traverses the sample. Note that darker chert follows heavy laminations possibly reflecting a chertification episode specific to interbedded portions of the laminated section.

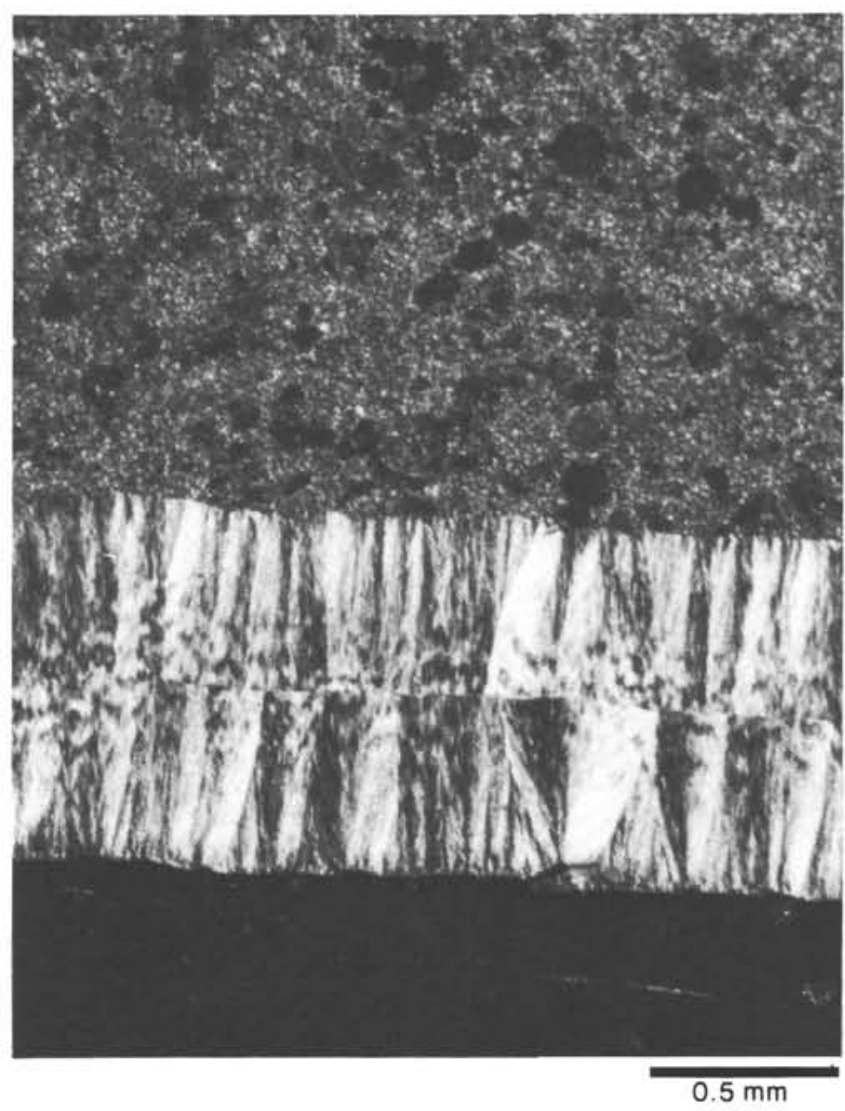

Figure 5. Photomicrograph of chert replacing silicified limestone halted by an impermeable vein of fibrous chalcedony (Sample 585-3-1, 31-33 cm), middle Eocene.

rences of chert within silicified rock either as nodules replacing earlier lithology or filling small cavities (Fig. 7). Microfossils and sedimentary structures such as laminae may be reduced to ghosts or entirely obliterated by chert replacement or, alternatively, they may be much better preserved in the chert than in the host chalk. What controls the obliteration versus preservation of original textures is not clear. The spacing of laminations preserved in chert falls within the range of those observed in host lithologies and thus offers little information about whether chertification was pre- or postcompaction (Figs. 4 and 8 ).

Both silicification and chertification occur most commonly where the host lithology is coarser, and chert and silicified limestone commonly display size grading of sediment constituents or lamination more clearly than the surrounding host (observed in Cores 585-3, 11, 14, 2326; Figs. 4 and 8). The coarse fraction comprises radiolarians and foraminifers. Many thin sections of chert from Hole 585 show grain size grading where it is not apparent in hand sample. The association of silicification and coarser (thus more porous and permeable) host sediment implies a need for pore water circulation in order for silicification to occur. This provides a physical reason for the greater frequency of chert and silicification associated with carbonate than with less permeable clay, in addition to the chemical arguments set forth by Kastner et al. (1977) and Kastner and Gieskes (1983). 


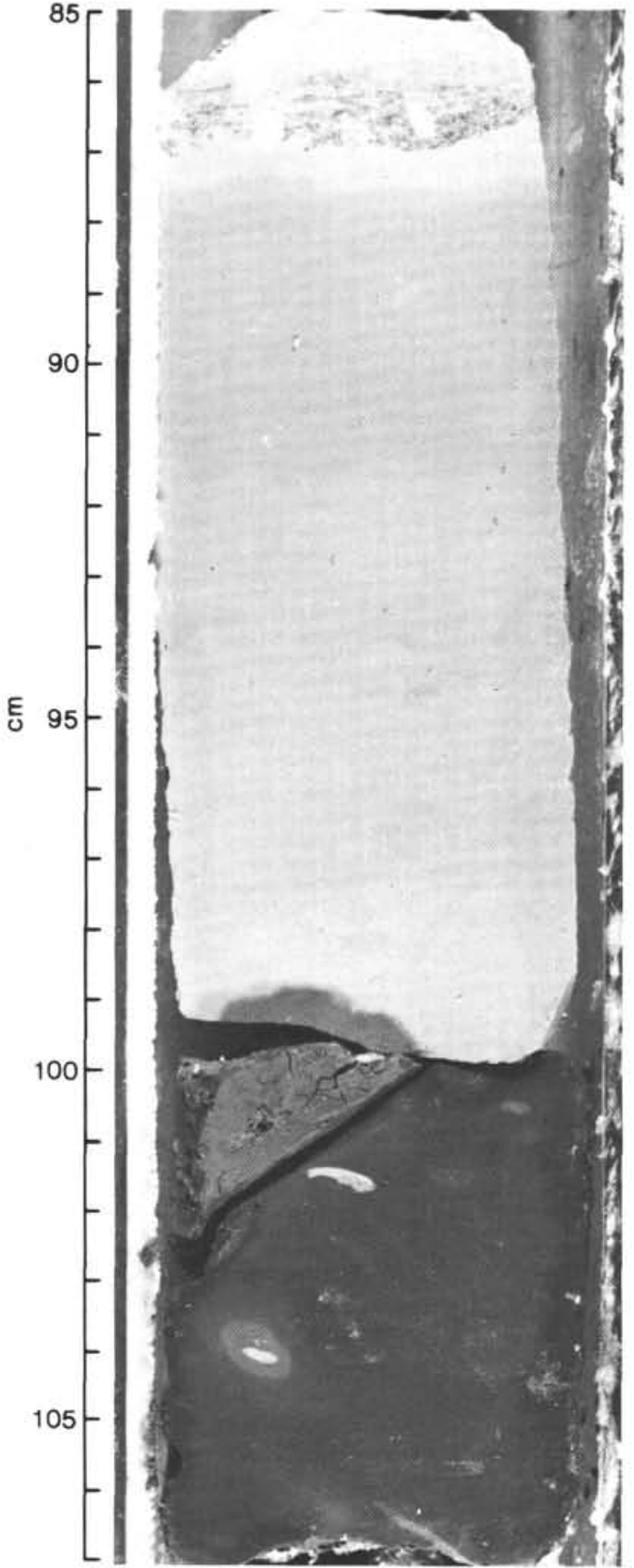

Figure 6. Sample 585-14-2, 85-107 cm, lower Eocene. Nannofossil chalk $(85-87 \mathrm{~cm})$, silicified nannofossil chalk $(87-100 \mathrm{~cm})$, and chert $(100-107 \mathrm{~cm})$. The degree of silicification increases downcore over this interval in observable increments of fuzzy to sharp outline: note several haloes of increasing shades of darkness at the base of the silicified chalk piece at about $100 \mathrm{~cm}$, whereas incompletely chertified vestiges of silicified limestone in the chert at $101.5 \mathrm{~cm}$ and $104 \mathrm{~cm}$ both exhibit sharp silicification outline. The vestige at $104 \mathrm{~cm}$ is surrounded by a halo of less silicified chalk.

\section{DISCUSSION}

In several of the examples illustrated in this chapter, it is implicit that silicification may have occurred more than once in a rock before the rock has been completely replaced by microcrystalline quartz. The sharp distinction between silicification (pore space infill) and cherti-

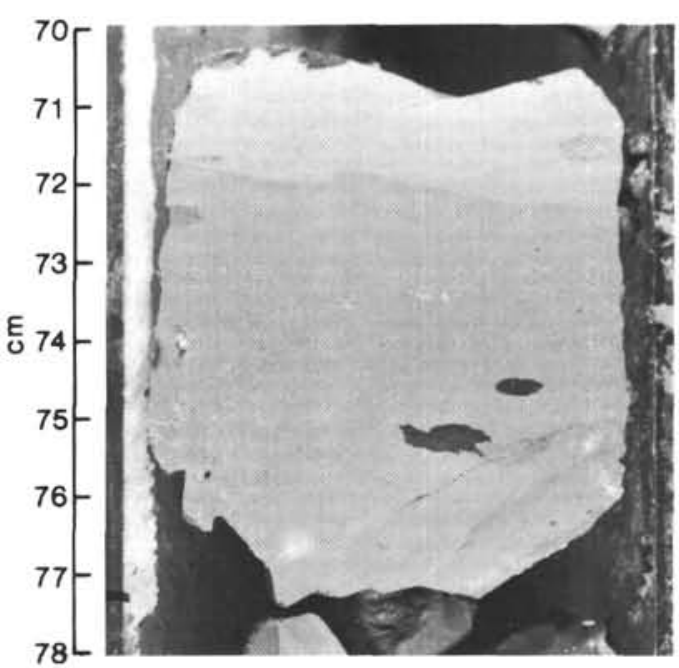

Figure 7. Sample 585-13-1, 70-78 cm, lower Eocene. Silicified nannofossil chalk with chert-filled cavities at 74.5 and $75.5 \mathrm{~cm}$. Crack in lower right corner is chert-filled with a local reduction halo in the lower left corner.

fication (complete replacement of host material) is an oversimplification; each event of silicification is probably accompanied by displacement of host material by dissolution to some degree. Postsilicification compaction of the unsilicified host lithology can reduce its volume relative to that of the silicified lithology.

Multiple silicification events may offer resolution to an enigma first pointed out by Keene (1976); material composed of opal-A must be reduced to about $10 \%$ of its original volume to produce the same amount of silica in the form of microcrystalline quartz. Keene proposed a physical contraction of earlier silica phases as a mechanism to accommodate the necessary volume reduction and suggested that the brecciated chert he observed during Leg 32 could result from such a process (Keene, 1975). Thus he postulated a widespread distribution of brecciated texture in authigenic silica on the seafloor. Alternatively, he also proposed that silica can be mobilized in solution over distances of several meters or even tens of meters and thus provide a silica supply to counter the volume reduction.

Results of this study favor the second mechanism both through lack of support for the first (no brecciated silica was observed at Site 585) and through evidence of multiple events of silicification over time. In comparing noncompacted silicified inclusions with their compacted equivalents in the host lithology we see that silicification occurred early in the sediment history, that is, before it was buried sufficiently to be compacted by the overburden of younger sediments. Even after the sediment was sufficiently indurated through compaction or through silicification to fracture and develop veins, it was still subject to further silicification or chertification (e.g., Fig. 5). Measurements of silicified limestone show that it retains significant porosity and could thus sustain further silicification.

Finally, the association of chert and silicified limestone with coarser portions of the host lithologies also reflects the role of porosity and permeability during si- 

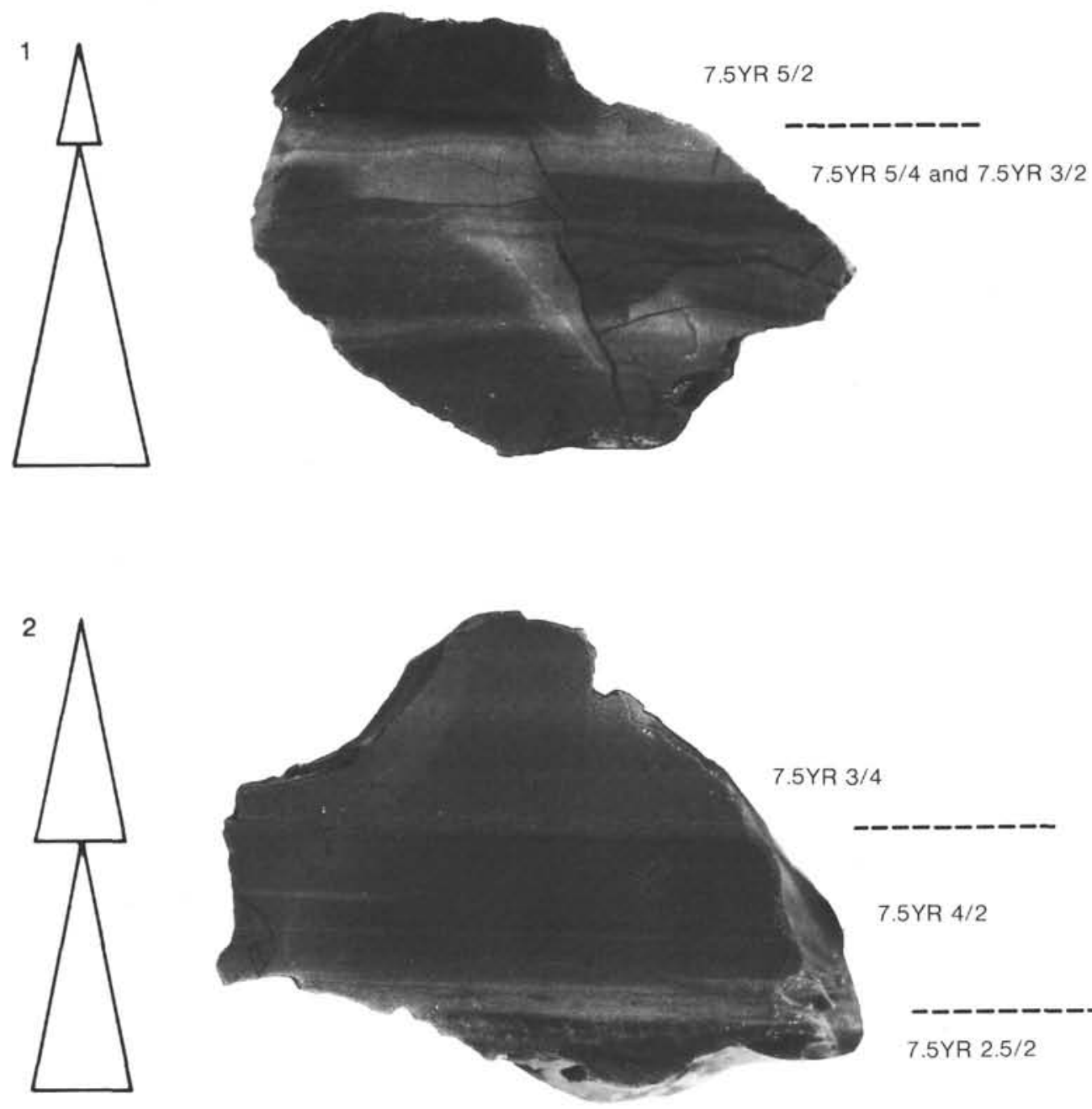

$7.5 Y R$ 4/2

7.5 YR $2.5 / 2$
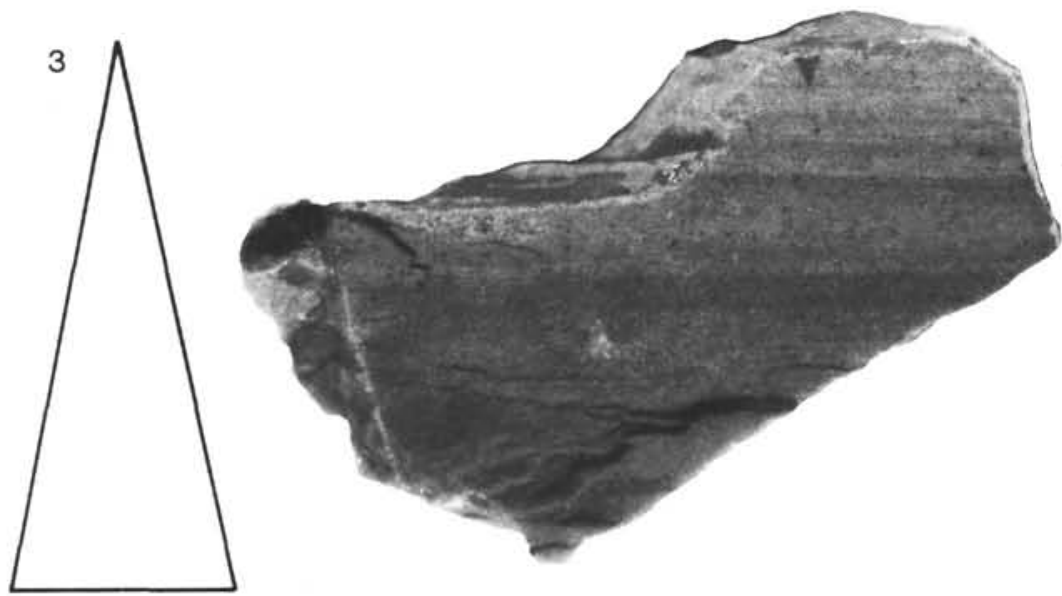

1OYR $4.5 / 3$

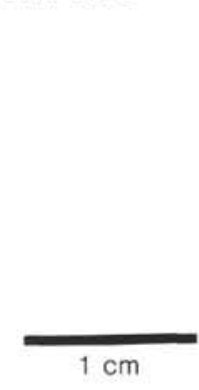

Figure 8. These three pieces of Campanian chert (Sample 585-23,CC) represent the total recovery of Core 585-23. All samples are graded (fining upward interval denoted by triangles), silicified bioclastic limestone. Casts of radiolarians and some foraminifers are observed in thin section. Munsell (1954) color codes to right of photograph indicate color of beds. Piece 1. A small graded interval of very dark brown color (7.5YR 5/2) overlies a graded interval of brown (7.5YR 5/4) and dark brown (7.5YR 3/2) with slightly lighter and darker shades. A chalcedony-filled vein truncates some color changes, indicating that some silicification events occurred after vein development. Piece 2 . A dark brown (7.5YR 3/4) graded interval of silicified bioclastic limestone overlies another graded interval of dark brown and brown (7.5YR 4/2 and 7.5YR 2.5/2) silicified bioclastic limestone. Grading is a function both of size and number of bioclasts (mostly radiolarian casts). Piece 3. A single graded interval of yellow brown (10YR 4.5/3) silicified bioclastic limestone. Chalcedony veins cut the lower part of the bed and coalesce with incipient stylolites subparallel to limestone in lower left region of sample. 
licification. Coarser and more porous material provides a better conduit for the delivery of dissolved silica and removal of dissolved carbonate as well as an open space for silica precipitation. The presence of clay probably impedes silicification not only chemically, through its surface adsorbtion of $\mathrm{Mg}(\mathrm{OH})_{2}$ (which acts as seeds for opal-CT precipitation), but physically, by reducing the porosity and permeability of the sediment.

\section{ACKNOWLEDGMENTS}

The author wishes to thank Walt Snyder and Jim Hein for their thoughtful reviews of this paper and Darren Trotter and Mark Richter for typing the original nearly illegible manuscript.

\section{REFERENCES}

Baltuck, M., 1983. Some sedimentary and diagenetic signatures in the formation of bedded radiolarite. In Iijima, A., Hein, J. R., and Siever, R. (Eds), Siliceous Deposits in the Pacific Region; Developments in Sedimentology (Vol. 36): New York (Elsevier), 299-316.

Calvert, S. E., 1974. Deposition and diagenesis of silica in marine sediments. Int. Assoc. Sedimentol. Spec. Pub., 1:273-299.

Heath, G. R., and Moberly, R., 1971. Cherts from the western Pacific Leg 7, Deep Sea Drilling Project. In Winterer, E. L., Riedel, W. R., et al., Init. Repts. DSDP, 7, Pt. 2: Washington (U.S. Govt. Printing Office), 991-1007.

Iijima, A., Hein, J. R., and Siever, R. (Eds.), 1983. Siliceous Deposits in the Pacific Region; Developments in Sedimentology (Vol. 36): New York (Elsevier).

Jones, J. B., and Segnit, E. R., 1975. Nomenclature and the structure of natural disordered (opaline) silica. Contrib. Mineral. Petrol., 51: 231-234.

Kastner, M., 1981. Authigenic silicates in deep sea sediments formation and diagenesis. In Emiliani, C. (Ed.), The Sea: The Oceanic Lithosphere (Vol. 7): New York (Wiley), 915-980.

Kastner, M., and Gieskes, J. M., 1983. Opal-A to opal-CT transformation: a kinetic study. In Iijima, A., Hein, J. R., and Siever, R.
(Eds.), Siliceous Deposits in the Pacific Region; Developments in Sedimentology, (Vol. 36): New York (Elsevier), 211-229.

Kastner, M., Keene, J. B., Gieskes, J. M., 1977. Diagenesis of siliceous oozes. I. Chemical controls on the rate of opal-A to opal-CT transformation-an experimental study. Geochim. Cosmochim. Acta, 41:1041-1059.

Keene, J. B., 1975. Cherts and porcellanites from the North Pacific, DSDP Leg 32. In Larson, R. L., Moberly, R., et al., Init. Repts. DSDP, 32: Washington (U.S. Govt. Printing Office), 429-507. 1976. The Distribution, mineralogy, and petrography of biogenic and authigenic silica from the Pacific basin [Ph.D. dissert.]. Scripps Institution of Oceanography, University of California, San Diego.

Kelts, K. R., 1976. Summary of chert occurrences from Line Islands Sites $314,315,316$, DSDP Leg 33. In Schlanger, S. O., Jackson, S. O., et al., Init. Repts. DSDP, 33: Washington (U.S. Govt. Printing Office), 855-870.

Lancelot, Y., 1973. Chert and silica diagenesis in sediments from the central Pacific. In Winterer, E. L., Ewing, J. I., et al., Init. Repts. DSDP, 17: Washington (U.S. Govt. Printing Office), 377-405.

Lancelot, Y., and Larson, R. L., 1975. Sedimentary and tectonic evolution of the northwestern Pacific. In Larson, R. L., Moberly, R., et al., Init. Repts. DSDP, 32: Washington (U.S. Govt. Printing Office), 925-939.

Munsell Color Company, 1954. Munsell soil color charts: Baltimore. (Munsell Color Co., Inc.)

Riech, V., and von Rad, U., 1979. Silica diagenesis in the Atlantic Ocean: diagenetic potential and transformations. In Talwani, M., Hay, W., and Ryan, W. B. F. (Eds.), Deep Drilling in the Atlantic Ocean: Continental Margins and Paleoenvironment, Am. Geophys. Union, Maurice Ewing Series, 3:315-340.

von Rad, U., and Rösch, H., 1972. Mineralogy and origin of clay minerals silica and authigenic silicates in Leg 14 sediments. In Hayes, D. E., Pimm, A. C., et al., Init. Repts. DSDP, 14: Washington (U.S. Govt. Printing Office), 727-739.

Wollast, R., 1974. The Silica Problem. In Goldberg, E. D. (Ed.), The Sea, (Vol. 5): New York (Wiley-Interscience), 359-392.

Date of Acceptance: 16 April 1985 